\title{
Sistem Pendukung Keputusan Pemilihan Handphone Dengan Metode Simple Additive Weighting Berbasis WEB
}

\author{
Aji Amijaya', FX. Ferdinandus², Muhaji Bayu ${ }^{3}$ \\ ${ }^{1}$ Sekolah Tinggi Teknologi Cahaya Surya Kediri \\ ${ }^{2}$ Sekolah Tinggi Teknik Surabaya \\ ${ }^{3}$ Sekolah Tinggi Teknologi Cahaya Surya Kediri \\ E-mail:ajiamijaya99@gmail.com,ferdi@stts.edu,muhajibayu_stt@cahayasurya.ac.id
}

\begin{abstract}
Abstrak
Pemilihan handphone sangatlah penting bagi kebutuhan setiap orang. Karena masing-masing orang memiliki kriteria tertentu dalam menentukan pilihannya. Ada sejumlah kasus yang ditemukan pada beberapa pengguna handphone mengaku salah dalam pemilihan handphone karena tidak mengetahui apa yang menjadi pertimbangan mereka untuk menentukan pilihan handphone yang tepat sesuai dengan kebutuhan mereka. Dengan adanya program "Sistem Pendukung Keputusan Pemilihan (SPK) Handphone Dengan Metode Simple Additive Weighting (SAW)" ini, peneliti berharap dapat membantu menyelesaikan masalah dalam pemilihan handphone yang sesuai dengan kebutuhan pengguna secara cepat dan efisien. Penelitian ini bertujuan untuk menghasilkan suatu sistem yang mampu membantu pengguna dalam menentukan pilihan handphone yang sesuai dengan kebutuhan mereka berdasarkan perhitungan dari bobot kriteria yang telah ditentukan untuk mendapatkan hasil perhitungan yang akurat..
\end{abstract}

Kata kunci: Pemilihan handphone, SAW, SPK

\section{Pendahuluan}

\subsection{Latar Belakang Masalah}

Perkembangan handphone di Indonesia sangat berkembang pesat sehingga sulit dipungkiri bahwa kehidupan kita sehari-hari dari berbagai profesi sangat bergantung pada handphone. Namun tidak berimbang dengan adanya sistem yang mendukung didalam pemilihan handphone yang tepat dan sesuai dengan kriteria masing-masing pribadi pengguna handphone. Meskipun banyak para pengguna handphone yang menggunakan fasilitas seperti mesin pencari, majalah handphone dan informasi dari teman. Metode tersebut kurang efektif dalam menentukan handphone apa yang sesuai dengan kriteria calon pengguna yang melibatkan beberapa faktor seperti pengguna yang ingin mencari handphone ᄀuntuk berfoto, bermain game, daya baterai yang tinggi, atau kapasitas memori yang besar yaitu dengan membandingkan beberapa kriteria seperti harga, RAM, memory internal, processor, kamera.

Dari permasalahan diatas maka sistem pendukung keputusan dengan metode SAW dapat menjadi salah satu solusi dalam menentukan pilihan handphone. Proses dari metode SAW tersebut adalah dengan menyeleksi beberapa handphone berdasarkan nilai dari kriteria serta dilakukan proses perangkingan agar mengetahui nilai tertinggi dan nilai terendah. 
Kemudian sistem akan menghasilkan kandidat handphone terbaik dari beberapa perbandingan tersebut. Hasil dari penelitian yang akan dibuat ini dapat memberikan kemudahan bagi orang yang akan memilih handphone dengan menentukan kriteria yang mereka tentukan sendiri dan akan menampilkan hasil rekomendasi terbaik dari beberapa alternatif yang dipilih oleh client.

\subsection{Tujuan Penelitian}

a. Menerapkan metode forward dan backward chaining untuk sistem informasi diagnosis penyakit demam berdarah.

b. Melakukan perbandingan hasil antara metode forward dan backward chaining.

\subsection{Pembatasan Masalah}

Peneliti membatasi masalah-masalah yang dibahas pada Tugas Akhir ini ke dalam ruang lingkup : Sistem pendukung keputusan ini hanya untuk pemilihan handphone yang resmi beredar di Indonesia, membangun sistem pendukung keputusan menggunakan metode $S A W$ berbasis web dengan kriteria secara umum: harga, RAM, memoru internal, kamera, processor, platform yang digunakan untuk membangun sistem ini yaitu bahasa pemrograman $P H P$ dan database MySQL.

\section{Landasan Teori}

\subsection{Sistem Pendukung Keputusan}

Sistem pendukung keputusan adalah proses pengambilan keputusan yang dibantu dengan suatu sistem menggunakan komputer. Dalam proses pengambilan keputusan tersebut harus dengan menggunakan beberapa data dan dengan menggunakan model tertentu agar dapat menyelesaikan beberapa masalah yang tidak terstruktur. Pada sebuah perusahaan atau organisasi, sistem pendukung keputusan dibuat bukan untuk menggantikan tugas menentukan keputusan, tetapi sebagai sarana yang membantu mereka dalam menentukan keputusan. Yaitu menggunakan data-data yang sudah diolah menjadi sebuah informasi untuk membantu pengambilan keputusan dari masalah-masalah semi-terstruktur.

Dalam pengimplementasiannya, hasil dari sistem bukanlah keputusan-keputusan yang bisa menjadi patokan, tahap keputusan tetap berada pada pengambil keputusan itu sendiri. Sistem hanya membantu mempertimbangkan keputusan agar mempermudah kerja pengambil keputusan dalam menentukan tahap akhir (Wibowo, 2011). Sistem pendukung keputusan dibuat untuk mendukung tahap pengambilan keputusan dari mulai mengidentifikasi permasalahan, memilih data relevan dan menentukan pendekatan yang digunakan dalam proses pengambilan keputusan hingga sampai mengevaluasi pemilihan alternatif yang ada (Fitriani, 2012).

\subsection{Pengertian Simple Additive Weighting (SAW)}

Simple additive weighting (SAW) merupakan metode yang digunakan untuk mencari suatu alternatif optimal dari sejumlah alternatif dengan kriteria tertentu. Salah satu metode yang digunakan untuk menyelesaikan masalah dari Fuzzy Multiple Attribute Decision Making (FMADM) adalah metode Simple Additive Weighting (SAW).

Definisi dari metode $S A W$ juga biasa disebut dengan istilah penjumlahan terbobot. Konsep dasar dari metode $S A W$ yaitu mencari penjumlahan terbobot dari rating setiap alternatif pada semua atribut (Pahlevy, 2010). Metode $S A W$ juga membutuhkan proses normalisasi matriks keputusan $\mathrm{X}$ ke suatu skala yang dapat diperbandingkan dengan semua rating alternatif yang ada. Formula untuk melakukan normalisasi tersebut adalah sebagai berikut (Kusumadewi, Harjoko, dan Wardoyo. 2006). 


\subsection{Pengertian Handphone}

Handphone adalah telepon selular dengan mikroprosesor, memori, layar dan modem bawaan. Handphone merupakan ponsel multimedia yang menggabungkan fungsionalitas $P C$ dan handset sehingga menghasilkan gadget yang mewah, dimana terdapat pesan teks, kamera, pemutar musik, video, game, akses email, tv digital, search engine, pengelola informasi pribadi, fitur GPS, jasa telepon internet dan bahkan terdapat telepon yang juga berfungsi sebagai kartu kredit (Williams \& Sawyer, 2011).

\subsection{Pengertian $W E B$}

Menurut Yuhevizar, web adalah metode untuk menampilkan sebuah informasi diinternet, baik itu berupa gambar, text, suara dan video maupun interaktif memiliki keuntungan yang dapat menghubungkan link dari dokumen satu dengan dokumen yang lainnya yang dapat diakses melalui sebuah browser.

\subsection{Pengertian PHP}

PHP sendiri merupakan sebuah bahasa pemrograman yang dipakai untuk membuat coding website dinamis yang memungkinkan kita untuk melakukan update pada website setiap saat. Berbeda halnya dengan markah HTML yang memuat source kode yang ditampilkan didalam website, sedangkan source code PHP sendiri tidak di tampilkan didalam halaman suatu website dikarenakan PHP diproses dan di olah didalam sebuah server, selain itu PHP juga bersifat server side script yang mampu dijalankan di beberapa system operasi seperti linux, windows, dll. Dalam database PHP memiliki kedinamisan yang bisa dihubungkan langsung dengan MySQL, Oracle. Namun untuk pemrograman websitenya sendiri yang digunakan adalah MySQL. PHP sampai saat ini telah mengalami kemajuan yang begitu pesat dan. untuk mengawali kode dalam PHP digunakan code <? Dan di tutup dengan code ?>

\subsection{Pengertian Data Flow Diagram}

Menurut Adi Nugroho DFD merupakan suatu diagram yang menggunakan simbolsimbol untuk menggambarkan sebuah sistem hubungan kerja antara fungsi-fungsi yang berkaitan satu sama lainnya dengan aliran serta penyimpanan data.

DFD sering dipakai sebagai penggambaran pada sistem yang telah ada ataupun sistem baru yang ditingkatkan secara logika tanpa pertimbangan dari singgungan fisik dimana data mengalir atau dimana data akan disimpan. Keuntungan dari pada menggunakan DFD ialah dapat mempermudah pemakai yang kurang memahami sistem komputer untuk mengerti sistem yang dikerjakannya.

DFD sendiri terdiri dari diagram kontek dan diagram rinci. Diagram kontek ialah suatu proses yang menggambarkan ruang lingkup sebuah sistem. Diagram kontek adalah level tertinggi dari DFD yng menggambarkan keseluruhan input ke sistem maupun output dari sistem. Dalam diagram kontek hanya memiliki satu proses saja. Tidak boleh ada dua proses dalam diagram konteks. Sedang kan diagram rinci menguraikan proses-proses apa saja dalam sebuah diagram level diatasnya.

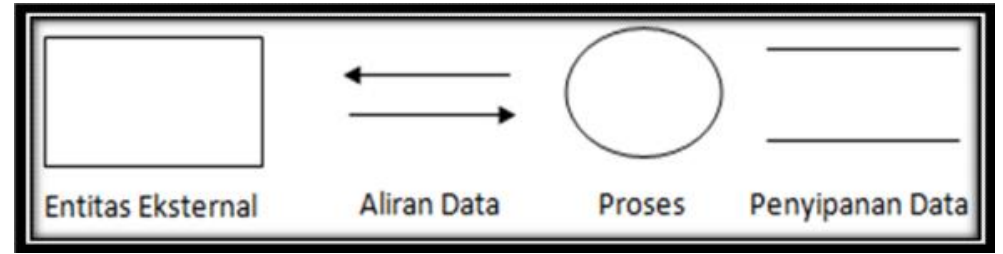

Gambar 2.1 Simbol-simbol DFD 


\subsection{Pengertian Entity Relationship Diagram}

Menurut Sutanta(2014), "Entity Relationship Diagram (ERD) merupakan suatu model data yang dikembangkan berdasarkan objek." Entity Relationship Diagram (ERD) digunakan untuk menjelaskan hubungan antar data dalam basis data kepada pengguna secara logis. Entity Relationship Diagram (ERD) didasarkan pada suatu persepsi bahwa real world terdiri atas obyek-obyek dasar tersebut. Penggunaan Entity Relationship Diagram (ERD) relatif mudah dipahami, bahkan oleh para pengguna yang awam. Bagi perancang atau analis sistem, Entity Relationship Diagram (ERD) berguna untuk memodelkan sistem yang nantinya, basis data akan di kembangkan. Model ini juga membantu perancang atau analis sistem pada saat melakukan analis dan perancangan basis data karena model ini dapat menunjukkan macam data yang dibutuhkan dan kerelasian antar data didalamnya.

Menurut Sutanta(2011)Komponen Entity Relationship Diagram (ERD):

1. Entitas Entitas merupakan suatu objek yang dapat dibedakan dari lainnya yang dapat diwujudkan dalam basis data. Objek dasar dapat berupa orang, benda, atau hal yang keterangannya perlu disimpan didalam basis data. Untuk menggambarkan sebuah entitas digunakan aturan sebagai berikut:

a. Entitas dinyatakan dengan simbol persegi panjang.

b. Nama entitas dituliskan didalam simbol persegi panjang.

c. Nama entitas berupa kata benda, tunggal.

d. Nama entitas sedapat mungkin menggunakan nama yang mudah dipahami dan dapat menyatakan maknanya dengan jelas.

2. Atribut Atribut merupakan keterangan-keterangan yang terkait pada sebuah entitas yang perlu disimpan dalam basis data. Atribut berfungsi sebagai penjelas pada sebuah entitas. Untuk menggambarkan atribut digunakan aturan sebagai berikut:

a. Atribut digambarkan dengan simbol ellips.

b. Nama atribut dituliskan didalam simbol ellips.

c. Nama atribut merupakan kata benda, tunggal.

d. Nama atribut sedapat mungkin menggunakan nama yang mudah dipahami dan dapat menyatakan maknanya dengan jelas.

3. Relasi Relasi merupakan hubungan antara sejumlah entitas yang berasal dari himpunan entitas yang berbeda. Aturan penggambaran relasi adalah sebagai berikut :

a. Relasi dinyatakan dengan simbol belah ketupat.

b. Nama relasi dituliskan didalam simbol belah ketupat.

c. Nama relasi berupa kata kerja aktif.

d. Nama relasi sedapat mungkin menggunakan nama yang mudah dipahami dan dapat menyatakan maknanya dengan jelas.

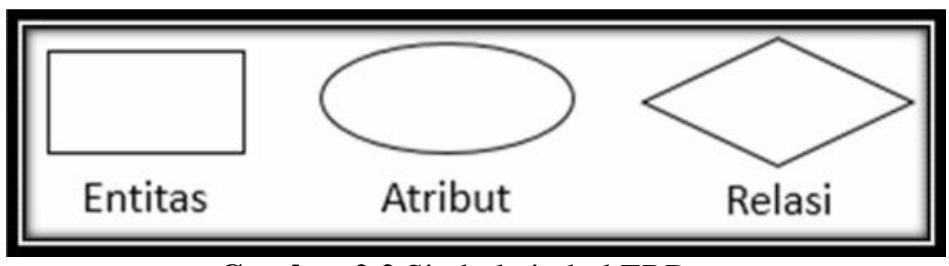

Gambar 2.2 Simbol-simbol ERD

\section{Perancangan Sistem}

\subsection{Rancangan Sistem}

Sistem pengolahan data sistem informasi rumah kost dapat digambarkan dalam bentuk berupa context diagram dan data flow diagram yang dapat dijelaskan pada subbab ini. 


\subsection{Analisi Kebutuhan Sistem}

Definisi kebutuhan sistem adalah faktor-faktor yang diperlukan oleh sistem dan diperlukan untuk perancangan perangkat lunak tersebut sesuai dengan maksud dan tujuan pembuatannya. Perancangan sistem pendukung keputusan pemilihan handphone ini membutuhkan perangkat lain sebagai pendukung agar pembuatan sistem ini dapat berjalan sesuai fungsi dan tujuannya.

\subsubsection{Analisis Kebutuhan Fungsional}

Kebutuhan fungsional adalah fungsi yang harus dipenuhi pada sistem yang dirancang dan memiliki keterkaitan langsung dengan sistem. Kebutuhan fungsional sistem ini adalah sebagai berikut:

a. Client dapat melakukan kewajibannya dengan melakukan pemilihan handphone sesuai dengan kriteria yang diinginkan.

b. Admin dapat melakukan kewajibannya dengan melakukan login dan mengolah sistem yang ada.

c. Sistem ini dapat menerima inputan data alternatif, kriteria dan subkriteria yang telah ditentukan.

d. Sistem menampilkan penilaian handphone yang sesuai dengan kriteria

e. Sistem menampilkan hasil perhitungan dari penilaian handphone berdasarkan perhitungan metode $S A W$.

\subsubsection{Analisis Kebutuhan Non-Fungsional}

Kebutuhan non fungsional adalah kebutuhan yang tidak secara langsung terkait dengan fitur tertentu dalam sistem. Kebutuhan non fungsional ini adalah sebagai berikut:

a. Kebutuhan perangkat keras

Kebutuhan perangkat keras dalam membangun sistem ini yaitu menggunakan laptop dengan merk dan spesifikasi sebagai berikut:

1. Asus Vivobook A407U

2. Intel® Core ${ }^{\mathrm{TM}} \mathrm{i} 3-6006 \mathrm{U}$ Processor, $2.0 \mathrm{GHz}$ (3M Cache)

3. Memory 4 GB DDR4

4. Storage 1 TB HDD 5400RPM

b. Kebutuhan perangkat lunak

Adapun perangkat lunak yang digunakan untuk membangun sistem ini adalah sebagai berikut:

1. Sistem operasi Windows 10

2. Web Browser Google Chrome

3. Xampp/Laragon

4. Sublime Text

\subsection{Context Diagram}

Langkah awal dalam pembuatan sistem pendukung keputusan adalah membuat Context Diagram yang merupakan top level. Context Diagram ini digunakan untuk memenuhi kebutuhan dari sistem dan output yang dihasilkan dari sistem yang dibuat penulis.Berikut gambaran sistem dengan context diagram. 


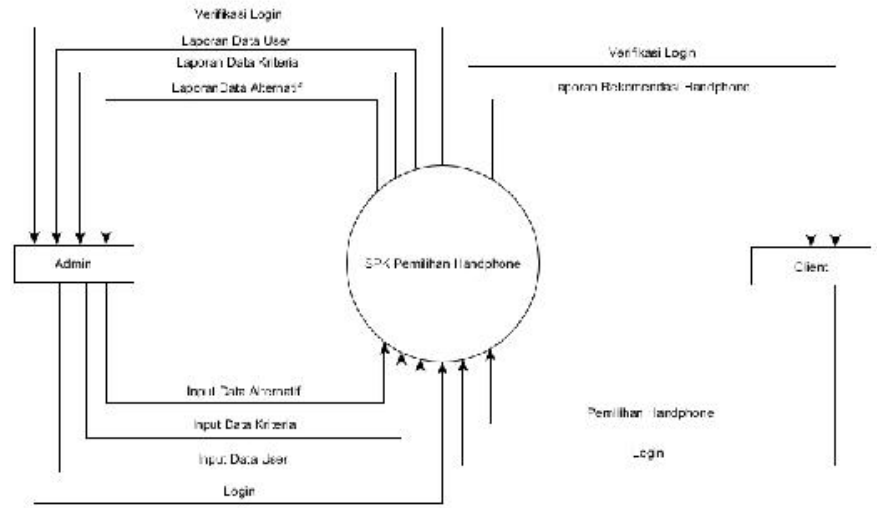

Gambar 3.1. Context Diagram

\subsection{Data Flow Diagram}

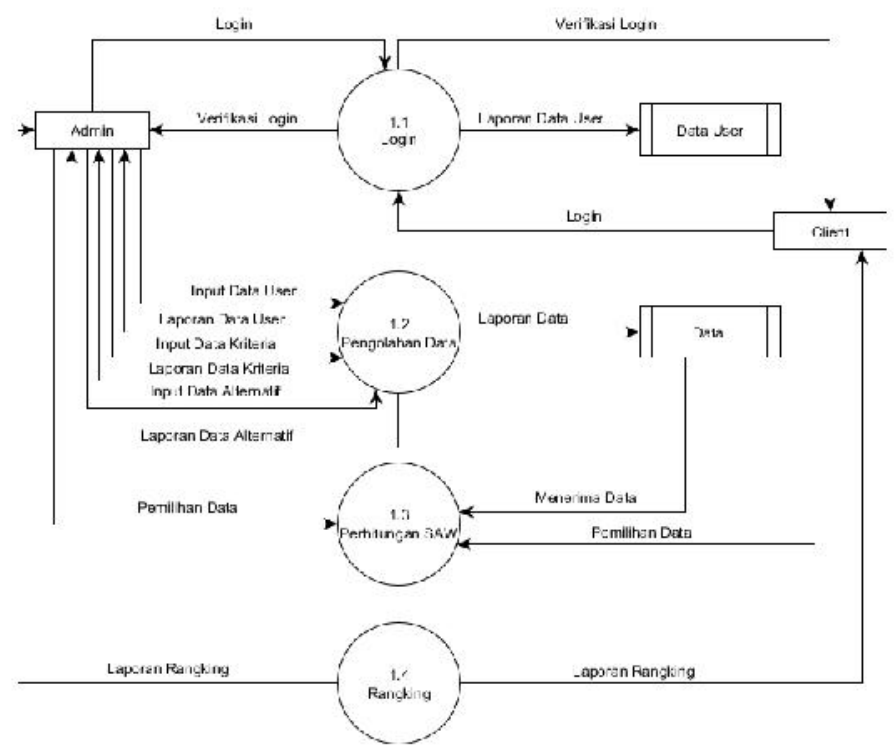

Gambar 3.2. Data Flow Diagram

Pada Data Flow Diagram ini merupakan pengembangan dari Context Diagram level demi level akan lebih jelas dipahami dalam bentuk DFD, diagram ini merupakan gambaran secara khusus dari sebuah aplikasi dengan penjelasan mendetail di dalam menganalisis "Sistem Pendukung Keputusan Pemilihan Handphone Dengan Metode Simple Additive Weighting Berbasis WEB'. Dan berikut gambaran sistem dengan Data Flow Diagram ( DFD ).

\subsection{Entity Relationship Diagram}

Merupakan salah satu bentuk pemodelan basis data yang sering digunakan dalam pengembangan sistem informasi. Diagram hubungan entitas (ERD) menunjukkan hubungan dari entitas set disimpan dalam database. Entitas dalam konteks ini adalah komponen data. Dengan kata lain, diagram ER menggambarkan struktur logis dari database. Sistem memiliki basis data relasional, dan ketentuannya bersifat top-down yang digunakan untuk menggambarkan model Entity-Relationship ini. ERD berfungsi untuk memodelkan struktur data dan hubungan antar data, untuk menggambarkannya digunakan beberapa notasi dan simbol. Gambar 3.3 menunjukkan Entity Relationship Diagram yang digunakan dalam pengembangan sistem. 


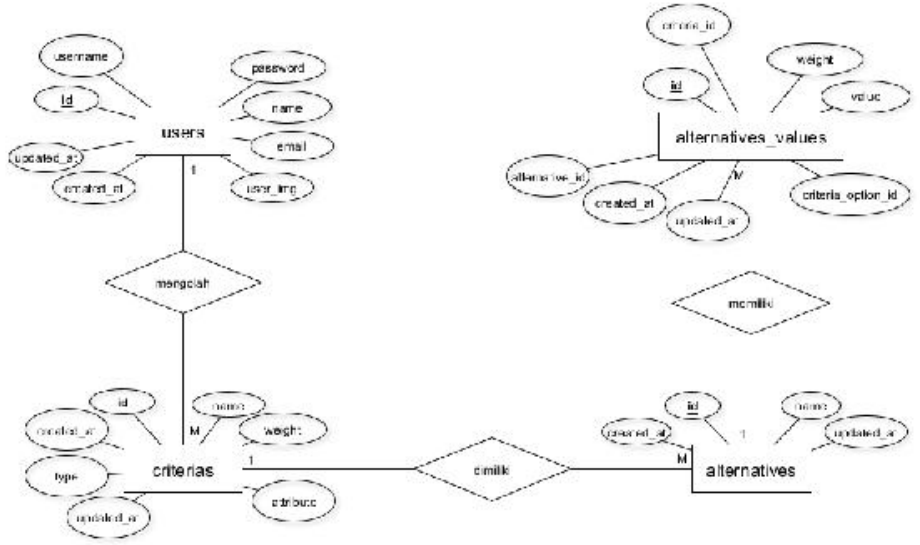

Gambar 3.3 Entity Relationship Diagram

\subsection{Rancangan Basis Data}

Dalam tahap perencanaan basis data ini, akan dijelaskan mengenai perancangan tentang database yang akan ada dalam sistem pendukung keputusan pemilihan handphone. Rancangan tabel-tabel dalam database sebagai berikut :

\subsubsection{Tabel User}

Tabel users ini berfungsi sebagai gerbang masuk sistem. Adapun field-field yang digunakan adalah :

Tabel 3.1 Tabel User

\begin{tabular}{|l|l|l|l|l|}
\hline No. & Field Name & Type & Size & Keterangan \\
\hline 1. & id & int & 10 & Primary Key \\
\hline 2. & username & varchar & 50 & \\
\hline 3. & password & varchar & 50 & \\
\hline 4. & name & varchar & 50 & \\
\hline 5. & email & varchar & 50 & \\
\hline 6. & user_img & varchar & 50 & \\
\hline 7. & previlege & char & 15 & \\
\hline 8. & created_at & timestamp & & \\
\hline 9. & uploaded_at & timestamp & & \\
\hline
\end{tabular}

\subsubsection{Tabel Criterias}

Tabel criterias digunakan sebagai tempat menampung data kriteria yang telah diinputkan sebelumnya. Adapun field-field yang digunakan adalah :

Tabel 3.2 Tabel Criterias

\begin{tabular}{|l|l|l|l|l|}
\hline No. & Field Name & Type & Size & Keterangan \\
\hline 1. & id & int & 10 & Primary Key \\
\hline 2. & name & varchar & 50 & \\
\hline 3. & attribute & varchar & 50 & \\
\hline 4. & type & varchar & 50 & \\
\hline 5. & weight & decimal & 7,2 & \\
\hline 6. & created_at & timestamp & & \\
\hline 7. & uploaded_at & timestamp & & \\
\hline
\end{tabular}

\subsubsection{Tabel Criterias Options}

Tabel criterias options digunakan sebagai tempat menampung data subkriteria yang telah diinputkan sebelumnya. Adapun field-field yang digunakan adalah : 
Tabel 3.3 Tabel Criterias Options

\begin{tabular}{|l|l|l|l|l|}
\hline No. & Field Name & Type & Size & Keterangan \\
\hline 1. & id & int & 10 & Primary Key \\
\hline 2. & criteria_id & int & 10 & Foreign Key \\
\hline 3. & name & varchar & 50 & \\
\hline 4. & value & decimal & 7,2 & \\
\hline 5. & created_at & timestamp & & \\
\hline 6. & uploaded_at & timestamp & & \\
\hline
\end{tabular}

\subsubsection{Tabel Alternatives}

Tabel alternatives digunakan sebagai tempat menampung data alternatif yang telah diinputkan sebelumnya. Adapun field-field yang digunakan adalah :

Tabel 3.4 Tabel Alternatives

\begin{tabular}{|l|l|l|l|l|}
\hline No. & Field Name & Type & Size & Keterangan \\
\hline 1. & id & int & 10 & Primary Key \\
\hline 2. & name & varchar & 50 & \\
\hline 3. & created_at & timestamp & & \\
\hline 4. & uploaded_at & timestamp & & \\
\hline
\end{tabular}

\subsubsection{Tabel Alternative Values}

Tabel alternative values digunakan sebagai tempat menampung data seperti jenis handphone, kriteria, subkriteria dan alternatif yang telah diinputkan sebelumnya. Adapun field-field yang digunakan adalah :

Tabel 3.5 Tabel Alternative Values

\begin{tabular}{|l|l|l|l|l|}
\hline No. & Field Name & Type & Size & Keterangan \\
\hline 1. & id & int & 10 & Primary Key \\
\hline 2. & alternative_id & int & 10 & Foreign Key \\
\hline 3. & criteria_id & int & 10 & Foreign Key \\
\hline 4. & criteria_option_id & int & 10 & Foreign Key \\
\hline 5. & weight & decimal & 7,2 & \\
\hline 6. & value & varchar & 50 & \\
\hline 7. & created_at & timestamp & & \\
\hline 8. & uploaded_at & timestamp & & \\
\hline
\end{tabular}

\section{Implementasi Dan Pembahasan}

Kegiatan setelah melakukan perancangan sistem adalah kegiatan implementasi dan pembahasan merupakan usaha untuk sistem yang dirancang efisien dimana yang nantinya apakah sistem baru yang diusulkan relevan atau tidak.

\subsection{Interface/Antarmuka Pengguna}

Interface merupakan bentuk tampian grafis yang berhubungan langsung dengan pengguna. Antarmuka pengguna berfungsi untuk menghubungkan antara pengguna dengan sistem. Sebuah antarmuka pengguna dirancang untuk berbagai sistem dan menyediakan cara untuk : Input, memungkinkan pengguna untuk memanipulasi sebuah system dan Ouput, memungkinkan sistem untuk menunjukkan hasil dari manipulasi pengguna.

Secara umum, tujuan dari teknik antarmuka adalah untuk mempermudah user dalam mengoperasikan komputer dan mendapatkan berbagai umpan balik yang diperlukan selama bekerja pada sebuah sistem komputer. Berikut adalah interface / antarmuka pengguna yang digunakan dalam sistem penentuan bantuan ini. 


\subsubsection{Tampilan Login}

Form ini adalah gerbang awal sebelum memasuki aplikasi yang digunakan untuk memasukkan username dan password agar dapat mengakses aplikasi. Bertujuan agar tidak sembarang orang bisa menggunakan aplikasi. Agar tingkat keamanan dan kerahasiaan dari data tetap terjaga. Gambar 4.1 menunjukkan tampilan login.

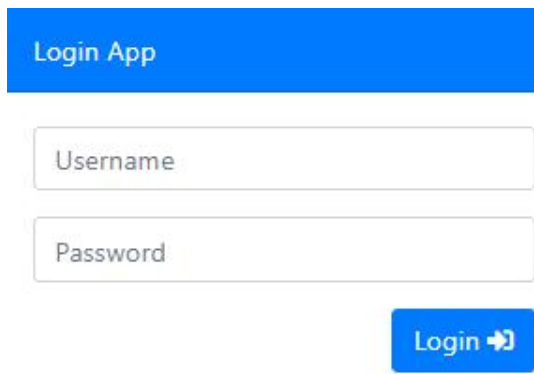

Gambar 4.1 Tampilan Login

\subsubsection{Tampilan Menu Admin}

Menu admin adalah halaman pertama yang muncul setelah user berhasil melakukan login sebagai admin. Pada halaman menu utama terdapat menu - menu yang ada dalam program diantaranya input data user, input data kriteria, input data alternatif, . Gambar 4.2 menunjukkan tampilan mеnи utama.

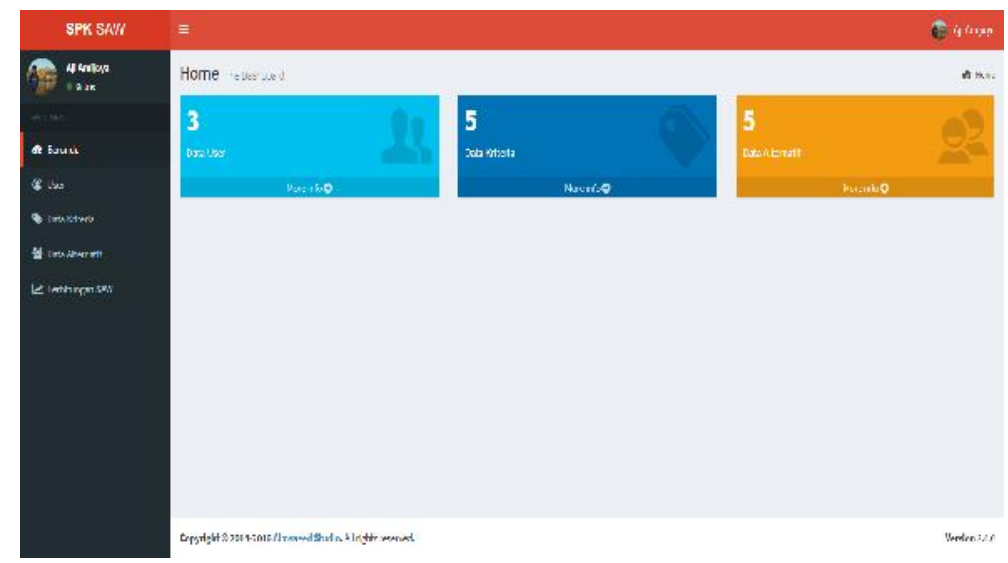

Gambar 4.2 Tampilan Menu Admin

\subsubsection{Tampilan Input User}

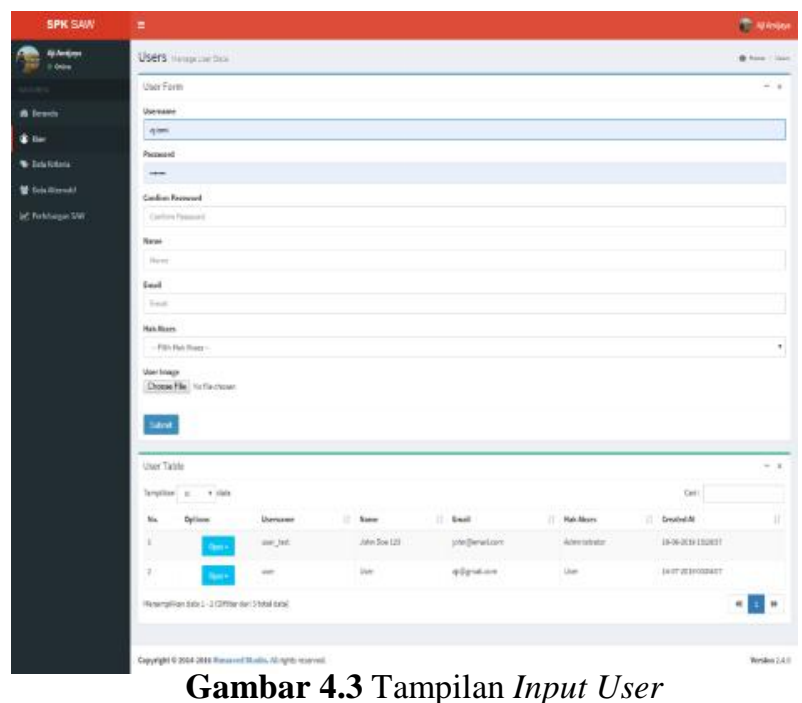

Gambar 4.3 Tampilan Input User 
Pada form ini admin dapat menginput user admin atau client. Jadi, setelah menginput data user, admin atau user tersebut dapat mengakses sistem.

\subsubsection{Tampilan Input Kriteria}

Pada form ini admin menambahkan kriteria seperti harga, RAM, memory internal, processor dan kamera. Kriteria tersebut digunakan sebagai bobot perhitungan untuk menentukan pilihan rekomendasi handphone terbaik. Gambar 4.4 menunjukkan tampilan menu input kriteria.

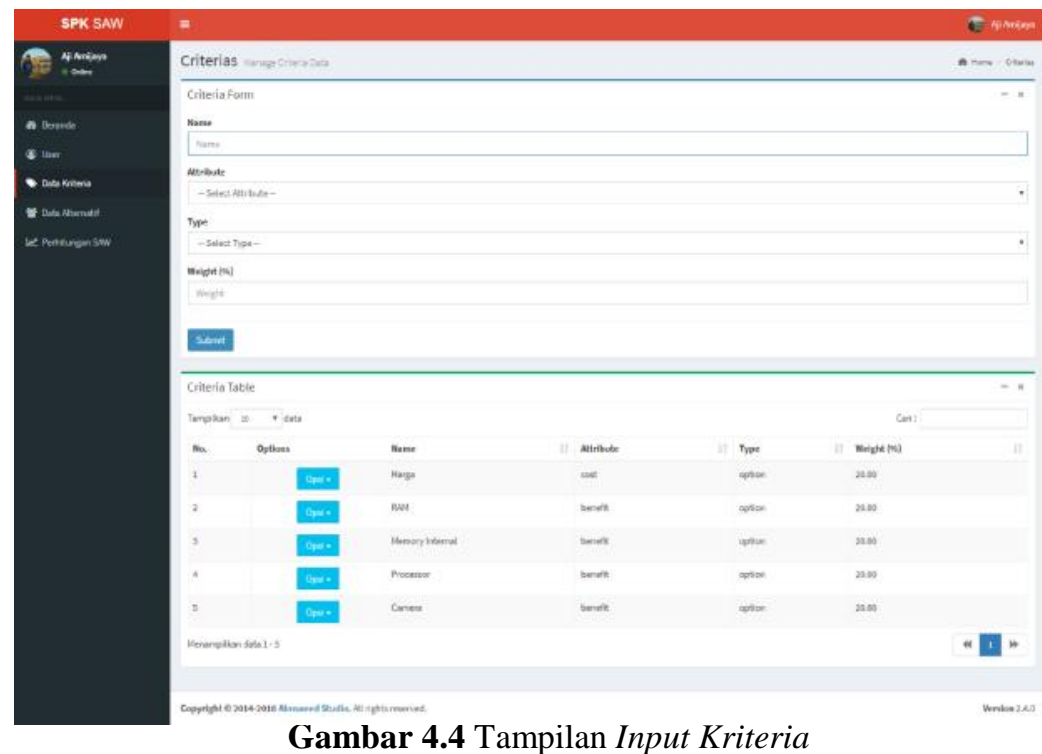

\subsubsection{Tampilan Input Alternatif}

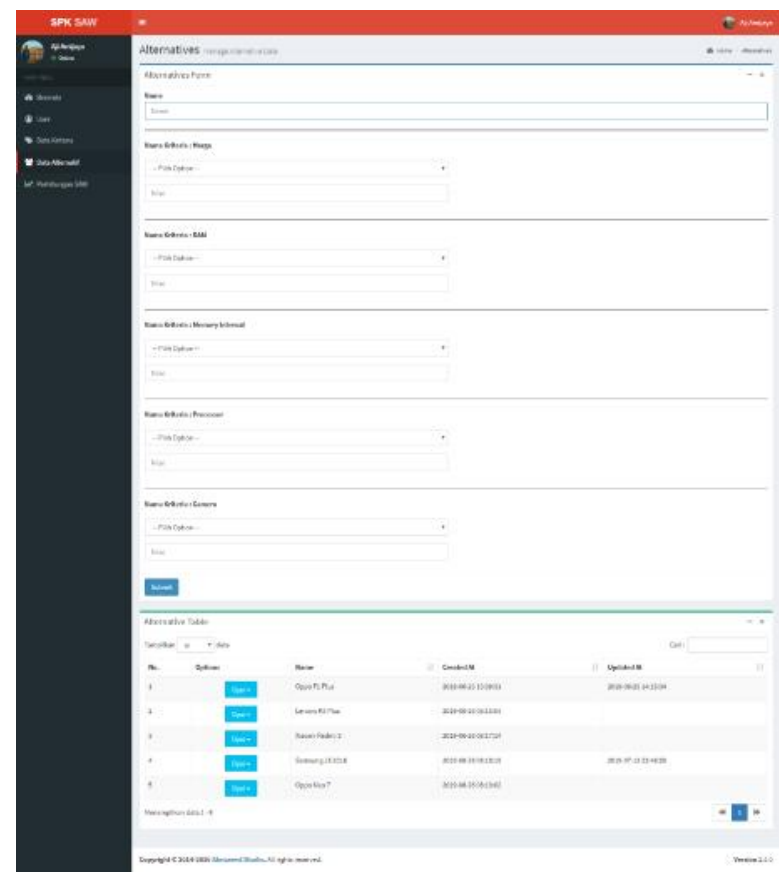

Gambar 4.5 Tampilan Input Alternatif

Pada form ini admin dapat menginout alternatif seperti jenis handphone dan spesifikasinya yang digunakan untuk melakukan perhitungan agar mendapat rekomendasi handphone yang sesuai kriteria client. Gambar 4.5 menunjukkan tampilan menu input alternatif. 


\subsubsection{Tampilan Menu User (Client)}

Form ini adalah menu dari client untuk mencari rekomendasi handphone yang sesuai dengan kriteria yang mereka pilih. Dalam menu ini user memilih beberapa jenis handphone untuk diuji mana yang memiliki nilai terbaik dari tiap bobotnya. Gambar 4.6 menunjukkan tampilan menu user (client).

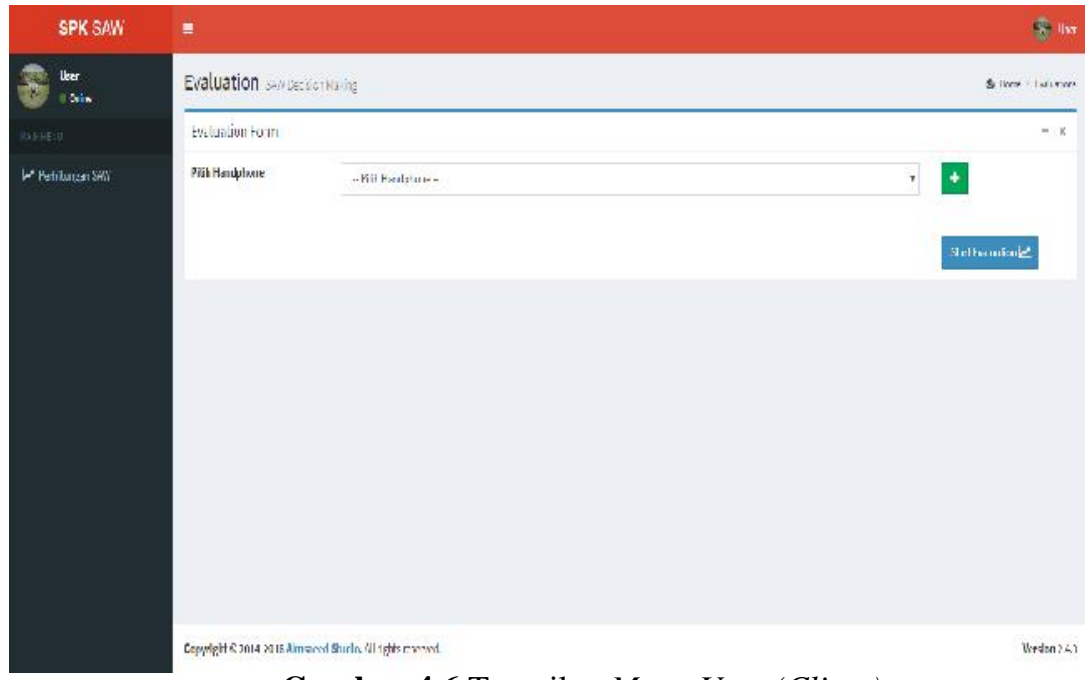

Gambar 4.6 Tampilan Menu User (Client)

\subsubsection{Tampilan Rekomendasi}

Form ini digunakan untuk memilih serta melihat hasil perhitungan dari sistem setelah memilih beberapa jenis handphone dan juga menampilkan rekomendasi terbaik dari pilihan tersebut. Gambar 4.7 menunjukkan tampilan menu rekomendasi.

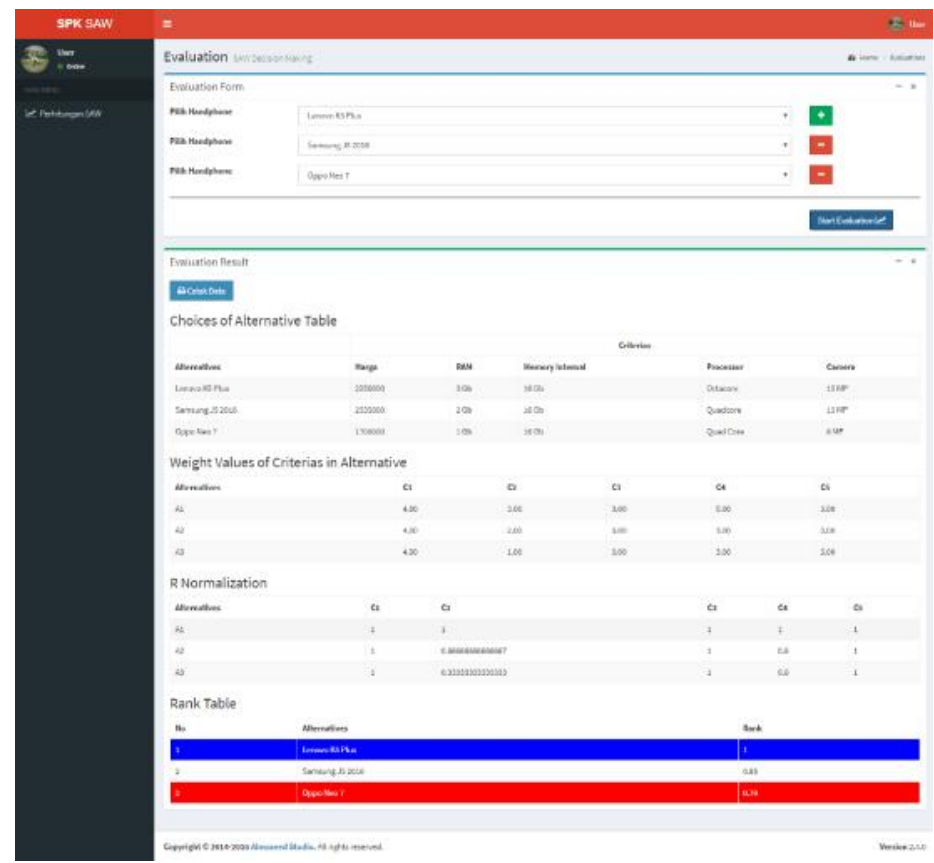

Gambar 4.7 Tampilan Rekomendasi

\section{Kesimpulan Dan Saran}

\subsection{Kesimpulan}

Berdasarkan pembahasan implementasi dan evaluasi dari bab-bab sebelumnya serta teori yang ada, maka dapat ditarik kesimpulan sebagai berikut : 
1. Dalam metode $S A W$ dapat digunakan untuk mencari alternatif terbaik dalam sistem pendukung keputusan pemilihan handphone yang sesuai dengan kriteria kebutuhan client.

2. Dari sistem pendukung keputusan ini diharapkan lebih mempermudah client dalam menentukan pemilihan handphone dengan rekomendasi terbaik.

\subsection{Saran}

Berdasarkan pengujian yang telah dilakukan pada sistem ini tentunya masih banyak kekurangan dan kelemahan yang terjadi sehingga perlu pengembangan lebih lanjut untuk kedepannya. Diharapkan nantinya akan ada pihak lain yang dapat mengembangkan penelitian ini menggunakan metode yang sama maupun yang lainnya. Peneliti memberikan saran untuk pengembangan dan peneliti yang akan datang, yaitu:

1. Melakukan analisis lebih lanjut terhadap penentuan batasan-batasan dari metode $S A W$.

2. Memberikan kriteria yang lebih spesifik untuk mendapatkan hasil yang lebih akurat agar dapat memenuhi kebutuhan pengguna dalam membantu menentukan pilihan handphone terbaik.

\section{References}

[1] Kadek Cahyadi (2016). Rancang Bangun Sistem Pendukung Keputusan Pemilihan Handphone Berbasis Web Dengan Metode FMADM. STMIK STIKOM Bali.Vol. II No 1.

[2] Harold Situmorang. (2015). Sistem Pendukung Keputusan Pemilihan Peserta Olimpiade Sains Tingkat Kabupaten Dengan Menggunakan Metode Simple Additive Weighting (SAW). Jurnal TIMES , Vol. IV No 2.

[3] Rizki Bagus Setiawan (2015). Sistem Pendukung Pemilihan Handphone Menggunakan Metode AHP (Analytical Hierarchy Process) Pada Counter Nasa Cell. Skripsi. S1 Teknik Informatika. Universitas Nusantara PGRI. Kediri.

[4] Hasan I, Pokok-Pokok Materi Teori Pengambilan Keputusan, Ghalia Indonesia, karta, 2002

[5] Syafii M, Membangun Aplikasi PHP dan MySQL, Andi, Yogyakarta, 2004

[6] Rifa.i, Fahrudin. (2016). Implementasi Sistem Pendukung Keputusan Pemilihan Gadget Terbaik dengan Metode Weight Product. Skripsi. Universitas Muhammadiyah Surakarta.

[7] Kristanto, Andri. 2008, Perancangan Sistem Informasi Dan Aplikasinya (Data Flow Diagram) Gava Media, Yogyakarta.

[8] Kurniawan. R, 2008, Pengertian Apache, Membangun Situs Dengan PHP Untuk Orang Awam, Maxikom, Palembang.

[9] S. W. Mudjanarko, S. Winardi, and A. D. Limantara, "Pemanfaatan internet of things (iot) sebagai solusi manejemen transportasi kendaraan sepeda motor," Pros. Semin. Nas. Apl. Teknol. Prasarana Wil. X, no. August, 2017.

[10] A. D. Triono et al., "Utilization of Pedestrian Movement on the Sidewalk as a Source of Electric Power for Lighting Using Piezoelectric Censors," in 2018 3rd IEEE International Conference on Intelligent Transportation Engineering, ICITE 2018, 2018.

[11] A. D. Limantara, L. D. Krisnawati, S. Winardi, and S. W. Mudjanarko, "Solusi Pengawasan Kebijakan Mengatasi Kemacetan Jalan dan Parkir Kota Berbasis Internet Cerdas," Semin. Nas. Teknol. dan Rekayasa Inf., no. November, pp. 1-6, 2017.

[12] A. D. Limantara, S. Winarto, and S. W. Mudjanarko, "Sistem Pakar Pemilihan Model Perbaikan Perkerasan Lentur berdasarkan Indeks Kondisi Perkerasan (Pci)," Semin. Nas. dan Teknol. Fak. Tek. Universtas Muhammadiyah Surakarta, no. November, pp. 1-2, 2017.

[13] A. D. Limantara, Y. Cahyo, S. Purnomo, and S. W. Mudjanarko, "Pemodelan Sistem Pelacakan LOT Parkir Kosong Berbasis Sensor Ultrasonic Dan Internet Of Things ( IOT ) Pada Lahan Parkir Diluar Jalan,” Semin. Nas. Sains dan Teknol., vol. 1, no. 2, pp. 1-10, 2017. 